Humaniora. Czasopismo Internetowe

$\mathrm{Nr} 1$ (33)/2021, ss. 127-145

\author{
KATARZYNA ROSIAK \\ Uniwersytet Warszawski \\ Wydział „Artes Liberales” \\ Stowarzyszenie Badań nad Zachodnim Ezoteryzmem \\ e-mail: katarzyna.rosiak@student.uw.edu.pl \\ ORCID: 0000-0003-1839-6667 \\ DOI: https://doi.org/10.14746/h.2021.1.6
}

\title{
Wizerunek masonerii jako organizacji satanistycznej na przykładzie publikacji Feliksy Eger
}

\begin{abstract}
In my paper I'm analysing an image of freemasonry in works of Feliksa Eger who wrote on this subject in XIX century. This paper is a an input to increase knowledge about an image of freemasonry and also about a phenomena of anti-masonry, understood as a world view choice, in which masonry becomes a source of all the evil on the world.

The aim of research was finding an answer on a question if it is possible to find in Feliksa Eger's publications an influence of confabulations of Léo Taxil, creator of satanistic black legend of freemasonry. Analysis of Feliksa Eger's publications, using such scientific methods as content analysis and image analysis proves that in her writings there were used motives described by Taxil. Additionally comparative analysis of texts also pays attention to an evolution of freemasonry image from rather negative image of freemasons as national enemies (category connected with a church's doctrine) to a very negative pop-cultural image in which freemasons are understood as a power of New World Order, category formed by Léo Taxil's publications. At the beginning the author presents masonry only as an organization endeavouring to take over the world and destroy Christianity. But in her last publication she describes freemasons as a Satanic sect ruled by Albert Pike.

Satanic image of freemasonry visible in Eger's works pays attention to the fact, how fast the myths created by Taxil were taken by other authors, copied and distributed by them.
\end{abstract}

Keywords: Léo Taxil, the masonry, satanism, Feliksa Eger, the image 


\section{Wstęp i metoda badań}

W oczach opinii publicznej na przestrzeni wieków funkcjonowały dwa przeciwstawne wizerunki ${ }^{1}$ wolnomularstwa ${ }^{2}$, zwane przez Ludwika Hassa, polskiego badacza dziejów masonerii, wersją „diaboliczną” i „hagiograficzną”, albo też „czarną” i „białą” legendą wolnomularstwa. To właśnie ten pierwszy, diaboliczny wizerunek zaadoptowała i rozpowszechniła kultura popularna, czyniąc go znanym na całym świecie, dzięki czemu stał się on immanentną częścią historii antymasonizmu, rozumianego jako wybór światopoglądowy, w ramach którego masoneria staje się źródłem wszelkiego zła.

Celem badania było znalezienie odpowiedzi na pytanie, czy w publikacjach Feliksy Eger (1835-1908), traktujących o masonerii, można zauważyć wpływ fantastycznych konfabulacji autorstwa Léo Taxila, XIX-wiecznego twórcy satanistycznej czarnej legendy masonerii. Dotychczas nikt jeszcze nie zajmował się tekstami Feliksy Eger, a praca ta jest pierwszą taką analizą tych publikacji w kontekście tekstów Léo Taxila.

W moich badaniach korzystałam z takich narzędzi, jak analiza zawartości przekazu oraz, będąca jej pochodną, analiza wizerunku. Dodatkowo, posiłkowałam się również analizą porównawczą. W procesie badawczym przydatne okazały się modele wizerunkowe, opracowane przeze mnie na potrzeby wcześniejszych badań i przypisane do dyferencjału semantycznego, czyli skali ocen rozmieszczonych między dwubiegunowymi określeniami:

++ to wizerunek bardzo pozytywny - wolnomularze jako „oświecona elita”;

+ to wizerunek raczej pozytywny - wolnomularze jako „nieszkodliwi ekscentrycy";

0 to wizerunek pozytywny - brak modelu, gdyż nie istnieją neutralne modele wizerunkowe;

- to wizerunek raczej negatywny - wolnomularze jako „wrogowie narodu”;

${ }^{1}$ Wizerunek to obraz danego podmiotu w świadomości odbiorcy. Więcej na temat wizerunku: Metody badania wizerunku w mediach. Czym jest wizerunek, jak i po co należy go badać, red. T. Gackowski, M. Łączyński, Warszawa 2009, s. 81.

${ }^{2}$ Wolnomularstwo jest to szczególny system etyki, osnuty alegoriami i przedstawiony za pomocą symboli, a odwołujący się do obrzędu wtajemniczenia. Więcej na temat definicji wolnomularstwa w: G. Di Bernardo, 1993, Definicja Masonerii, tłum. J. Wysocka, „Ars Regia. Czasopismo poświęcone myśli i historii wolnomularstwa” 1993, rok 2, nr 1(2), ss. 7-12.

${ }^{3}$ W swoim poprzednim artykule (K. Rosiak, Wizerunek masonerii w polskich memach internetowych, ss. 105-136, w: Memy czyli życie społeczne w czasach kultury obrazu, red. T. Gackowski, K. Brylska, M. Patera, CeDeWu, Warszawa 2017), w którym po raz pierwszy wykorzystałam opracowane przeze mnie kategorie, stosowaną przeze mnie nazwą dla wizerunku raczej negatywnego masonerii była kategoria „wrogowie Polski”. Na podstawie uzyskanych przeze mnie nowych wyników badań zdecydowałam się na zmianę nazwy na „wrogów narodu”, 
- - to wizerunek bardzo negatywny - wolnomularze jako „władza Nowego Porządku Świata”.

Dla poszczególnych modeli opracowałam klucz kategoryzacyjny, czyli przypisane do modelu określenia i symbole, pozwalające rozpoznać, którym modelem posługuje się autor danej publikacji. Warto też zauważyć, iż w ramach jednego przekazu mogą występować dwa lub więcej wizerunków masonerii, co skutkuje powstaniem wizerunku mieszanego.

1. „oświecona elita”: nacisk w materiałach położony jest na osiągnięcia wolnomularzy oraz opisy dokonań sławnych przedstawicieli masonerii (na przykład Wolfganga Amadeusza Mozarta, George’a Washingtona, ks. Józefa Poniatowskiego, prezydenta USA Woodrowa Wilsona, prezydenta RP Gabriela Narutowicza); są to zazwyczaj materiały o tematyce historycznej lub promocyjnej, niekiedy wyprodukowane przez samych wolnomularzy bądź organizacje w jakiś sposób z nimi powiązane; kategoria ta odpowiada wspomnianej wyżej białej legendzie wolnomularstwa opisanej przez Ludwika Hassa;

2. „nieszkodliwi ekscentrycy”: w treści pojawiają się opisy dziwnych rytuałów, strojów i symboliki używanej przez wolnomularzy; jest to zazwyczaj groteskowe, prześmiewcze bądź absurdalne przedstawienie masonerii, a sami autorzy często drwią również z teorii spiskowych oraz popularnych przedstawień wolnomularstwa;

3. „wrogowie narodu”: treść przekazów skupia się na tematach takich jak walka masonerii z Kościołem katolickim (lub ogólnie chrześcijaństwem) oraz państwem narodowym. Często opisywane są w nich powiązania masonów ze światem polityki, rzekoma infiltracja Kościoła katolickiego od wewnątrz, wpływ na wydarzenia w Polsce i na świecie, a także światowy spisek. Wydarzenia te zazwyczaj analizowane są jednak w kontekście losów Polski (lub innego kraju, w zależności od narodowości autora antymasońskiej publikacji), która w owych teoriach wydaje się być głównym celem masonerii, na równi ze zniszczeniem Kościoła katolickiego. Autorzy podobnych materiałów najczęściej wywodzą się ze środowisk ultraprawicowych i konserwatywnych, zarazem blisko powiązanych z Kościołem. Wizerunek ten wydaje się wyrastać z historii masońskiego spisku opisanej przez ojca Augustina Barruela w Historii jakobinizmu ${ }^{4}$ oraz antymasońskiego stanowiska zajmowanego przez wiele lat przez Kościół katolicki;

4. „władza Nowego Porządku Świata”: autorzy utożsamiają wolnomularzy z sektą Iluminatów oraz z Żydami ${ }^{5}$ i opowiadają o kultywowaniu w lożach satanizmu, ich sekretnym wpływie wywieranym jakoby na takie sfery życia, jak

którą uważam za właściwszą, z uwagi na poszerzenie znaczeniowe pojęcia, tj. włączenie do kategorii również innych państw narodowych.

${ }^{4}$ Więcej na ten temat $\mathrm{w}$ dalszej części tekstu.

${ }^{5} \mathrm{~W}$ artykule zastosowana została pisowania z wielkiej litery, choć jak wiadomo dokonuje się rozróżnienia na Żydów (członków narodu) oraz żydów (wyznawców judaizmu). Dla Feliksy Eger, autorki omawianych w tym artykule tekstów, Żyd, do którego odnosi się w swoich publikacjach, to zarówno członek narodu, jak i wyznawca judaizmu, stosujący się do nauczania Talmudu. Eger 
gospodarka, polityka, show-biznes, a które stają się środkami do realizacji ogólnoświatowego spisku. Ten wizerunek jest silnie powiązany z nurtem antymasonizmu popkulturowego.

Analiza publikacji Feliksy Eger, takich jak: Historia towarzystw tajnych. Dzieje wolnomularstwa (masonii). Według najlepszych źródeł opracowane (1894), Kilka słów o masonerii (1901), Żydzi i masoni we wspólnej pracy (1908) pozwala stwierdzić, iż autorka prezentuje zdecydowanie negatywny wizerunek wolnomularstwa, opisując je jako organizację satanistyczną, dążącą do przejęcia władzy nad światem i unicestwienia chrześcijaństwa.

\section{Teoria spiskowa}

Kluczowym terminem dla zrozumienia poruszanej w artykule problematyki jest „teoria spiskowa”. Badacze historii idei są zgodni, iż w ostatnich dziesięcioleciach XVIII wieku i na początku wieku XIX wieku pojęcie „spisku” stało się jedną z popularnych i podstawowych kategorii politycznych objaśniających niezrozumiałe zjawiska. Zdaniem historyka Lecha Zdybla studia nad spiskową teorią dziejów pozwalają zrozumieć korzenie jej współczesnej wersji, pewnych metod manipulacji i politycznej propagandy, a konspiracjonizm do dziś stanowi znaczący element społecznej świadomości ${ }^{6}$.

Jako pierwszy analizę fenomenu teorii spiskowych przeprowadził Karl R. Popper w The Open Society and Its Enemies (Społeczeństwo otwarte i jego wrogowie, 1945), gdzie podjął krytykę poglądu określonego przez niego jako „spiskowa teoria społeczeństw” (conspiracy theory of society) ${ }^{7}$. Obecnie w literaturze znaleźć można kilkanaście różnych definicji teorii konspiracji. Daniel Pipes, autor klasycznej już Potęgi spisku. Wpływ paranoicznego myślenia na dzieje ludzkości, definiuje ją jako „obawę przed spiskiem, którego nie ma”. Psycholog Krzysztof Korzeniowski wskazuje jednak na słaby punkt owego wyjaśnienia, pytając, w jaki sposób można się upewnić, iż owego spisku faktycznie nie ma? ${ }^{9}$ Wydaje się, że lepsze wytłumaczenie terminu proponuje Robert Brotherton, także psycholog, który stwierdza, iż teoria spiskowa to niezweryfikowane przeświadczenie o istnieniu spisku, w sytuacji, w której spisek nie wydaje się w przekonujący sposób wyjaśniać

używa obu form zapisu w swoich tekstach (na przykład w Kilka słów o masonerii - zapis małą literą, natomiast w Żydzi i masoni we wspólnej pracy - wielką), uznając je za tożsame.

${ }^{6}$ L. Zdybel, Idea spisku i teorie spiskowe w świetle analiz krytycznych i badań historycznych, Lublin 2002, s. 25.

7 Ibidem, ss. 7-8.

${ }^{8}$ D. Pipes, Potęga spisku. Wpływ paranoicznego myślenia na dzieje ludzkości, Warszawa, 1998, s. 40.

${ }^{9}$ K. Korzeniowski, O dwóch psychologicznych przesłankach myślenia spiskowego. Alienacja czy autorytaryzm, „Psychologia Społeczna”, 2009, t. 4, nr 3(11), s. 144, http://www.spoleczna. psychologia.pl/pliki/2009_3/Korzeniowski_PS_2009_3.pdf [dostęp: 13.03.2019]. 
danego zdarzenia ${ }^{10}$. Z kolei zdaniem Cassa Sunsteina i Adriana Vermeule’a, jurystów z Uniwersytetu Harvarda, daną teorię uznać można za teorię spiskową, jeśli wyjaśnia ona jakieś wydarzenie lub praktykę za pomocą intrygi zawiązanej przez ludzi mających duże wpływy i którzy owe wpływy starają się ukryć do momentu, gdy osiągną swój cel ${ }^{11}$.

Pipes wymienia w swojej pracy trzy wyróżniki konstrukcji teorii spiskowej: wystąpienie potężnej, zakonspirowane organizacji, dążącej do ogólnoświatowej hegemonii, nieświadomych wykonawców i agentów, którzy wykonują polecenie owej organizacji, oraz osaczoną ze wszystkich stron grupę, która potrzebuje pomocy, by powstrzymać realizację owego złowieszczego planu ${ }^{12}$. Ciekawej analizy zjawiska dokonał również Chip Berlet, autor studium Toxic for Democracy. Conspiracy theories, demonization and scapegoating (Toksyczne dla demokracji: teorie spiskowe, demony i kozły ofiarne ${ }^{13}$, 2009) . Zdaniem Berleta narracja teorii konspiracji opiera się na czterech kluczowych elementach, zwanych przez niego „narzędziami strachu” (tools of fear). Są nimi: 1) dualizm, czyli uproszczony podział świata na dobro i zło; 2) kozioł ofiarny, którego można oskarżyć o społeczne problemy, których prawdziwe źródło leży gdzie indziej; 3) demonizacja, która pozwala wskazać i ucieleśnić źródło zła; 4) apokaliptyczna agresja, tj. oczekiwanie na ostateczne rozwiązanie, które doprowadzi do bitwy pomiędzy dobrem i złem ${ }^{14}$.

Jak z kolei wyjaśnia Jovan Byford, autor Conspiracy theories: A Critical Introduction (Teorie spiskowe: wprowadzenie krytyczne, 2011), teorie spiskowe pełnią dwie ważne funkcje: $\mathrm{z}$ jednej strony dostarczają ram pozwalających na opisanie znaczących i dramatycznych wydarzeń, z drugiej zaś strony obnażają rzekomą prawdę o mechanizmach rządzących światem ${ }^{15}$. Historyk Janusz Tazbir podkreśla, iż istnieje trwające do dziś zapotrzebowanie na wyjaśnianie wszystkich ważniejszych wydarzeń za pomocą teorii spiskowej ${ }^{16}$. Atrakcyjność teorii spiskowych, zgodnie ze słowami historyka Isaiaha Berlina, opiera się przede wszystkim na

${ }^{10}$ R. Brotherton, Towards a definition of 'conspiracy theory', „PsyPAG Quarterly” 2013, nr 88(3), ss. 9-14, za: M. Grzesiak-Feldman, Psychologia myślenia spiskowego, Warszawa 2016, ss. 18-19.

${ }^{11}$ C. Sunstein, A. Vermeule, Conspiracy Theories: Causes and Cures, "The Journal of Political Philosophy” 2009, XVII, nr 2, ss. 202-227, za: J. Guzowski, Psychologiczne źródła teorii spiskowych, „HYBRIS” (2016), nr 33, s. 88, http://hdl.handle.net/11089/20139 [20.12.2019].

${ }^{12}$ D. Pipes, Potęga spisku..., s. 41.

13 Tłumaczenia tytułów publikacji w artykule są autorstwa autorki, o ile nie wskazano inaczej.

${ }^{14}$ W oryginale: „1) Dualism; 2) Scapegoating; 3) Demonization; and 4) Apocalyptic Aggression”. Por. Ch. Berlet, Toxic Democracy. Conspiracy theories, demonization and scapegoating, „Political Research Associates” 2009, ss. 2-3, https://www.academia.edu/6928596/Toxic_to_Democracy_Conspiracy_Theories_Demonization_and_Scapegoating [dostęp: 20.12.2019].

15 J. Byford, Conspiracy theories: A Critical Introduction, Basingstoke 2011.

16 J. Tazbir, Najnowsze publikacje na temat Protokołów mędrców Syjonu, „Dzieje Najnowsze” 1992, R. XXIV, nr 4, s. 75. 
uproszczonym obrazie rzeczywistości, jaki oferują, złudnej łatwości wyjaśnienia skomplikowanych i często niezrozumiałych zjawisk i procesów ${ }^{17}$.

Badacze w różny sposób wyznaczają początkową cezurę pojawienia się w dyskursie społecznym spiskowej teorii dziejów - Popper uznaje, że konspiracjonizm sięga korzeniami czasów Homera, z kolei Tazbir uważa, że tego rodzaju mity pojawiły się dopiero w średniowieczu. Większość uczonych zgadza się jednak, że prawdziwy rozkwit teorii spiskowych przyniosła Rewolucja Francuska, którą ówczesna konserwatywna opozycja uznała za konspirację mającą na celu zniszczenie odwiecznego porządku opartego na chrześcijaństwie ${ }^{18}$. Wydana wówczas przez eksjezuitę Augustina Barruela (1741-1820) czterotomowa rozprawa Mémoires pour servir à l'Histoire du Jacobinisme (1797-1799) ${ }^{19}$ nadała światowy rozgłos teoriom spiskowym na temat wolnomularstwa. Barruel opisał w niej historię antychrześcijańskiej konspiracji zawiązanej przez Woltera oraz jego masońskich braci, którą przepowiedzieć miał zdaniem byłego duchownego sam św. Jan na łamach Apokalipsy ${ }^{20}$. Jednak dopiero jego następca, Léo Taxil, wprowadził antymasonizm w nurt kultury popularnej, nadając opracowanym przez siebie teoriom spiskowym prawdziwie światowy rozgłos.

\section{Léo Taxil - twórca satanistycznej legendy}

Léo Taxil (właśc. Gabriel-Anotoine Jogand-Pages; 1854-1907) to urodzony w religijnej francuskiej rodzinie wydawca licznych publikacji na tematy głównie antykościelne i antymasońskie oraz samozwańczy „największy figlarz wszechczasów”21. Po naznaczonym licznymi konfliktami okresie edukacji w jezuickim seminarium, Taxil rozpoczął karierę wojowniczego antyklerykała. Już wówczas nie unikał wymysłów i konfabulacji - przykładowo duchownych z katedry Notre Dame oskarżył o sekretną naprawę narzędzi tortur w katedralnych katakumbach, które miały im rzekomo posłużyć do przywrócenia francuskiej monarchii ${ }^{22}$. Opublikował wiele antyklerykalnych tekstów, w których atakował hipokryzję ówczesnych kapłanów, o takich tytułach, jak: Les Soutanes grotesques (Groteskowi sukienkowi, 1879),

${ }^{17}$ I. Berlin, Nie wiemy, gdzie jest port, trzeba więc płynq̨ć, w: G. Sorman, Prawdziwi myśliciele naszych czasów, tłym. M. Miszalski, Warszawa 1993, s. 360.

18 L. Zdybel, Idea spisku i teorie spiskowe..., s. 11.

19 Książki, przetłumaczone przez ks. Karola Surowieckiego, ukazały się po polsku w dwóch wersjach: jako okrojone streszczenie zatytułowane Tajemnice masonerii sprofanowane (1805) oraz jako Historia jakobinizmu wyjęta z dzieła księdza Barruela (1812).

20 T. Cegielski, Od papieskiej bulli do tabloidu. Krótki zarys dziejów antymasonizmu, „Hermaion” 2015, nr 4, ss. 43-45.

${ }^{21}$ K. McLeod, Pranksters: Making Mischief in the Modern World, NYU Press, New York, 2014, s. 109.

22 D.A. Harvey, Lucifer in the City of Light, „Ritual \& Witchcraft” Winter 2006” t. 1, nr 2, s.181. 
Le Fils du jésuite (Jezuicki syn, 1879) czy Les Bêtises sacrées, revue critique de la superstition (Święta głupota czyli krytyczny przegląd przesądów, 1880). W efekcie Taxil został oskarżony o wielokrotne łamanie prawa prasowego i do 1876 roku stanął przed sądem aż 13 razy 23 (!). Ratując się przed czekającym go we Francji więzieniem, uciekł do Genewy, skąd wkrótce został zresztą wydalony pod zarzutem kolejnego oszustwa. W 1880 roku całkowicie zerwał więzy łączące go z rodziną i przyjął imię Léo Taxila. Dopiero amnestia z 1882 roku pozwoliła mu na powrót do kraju.

W 1882 roku ukazała się La Bible amusante (Cudowna biblia dla dzieci i dorosłych), satyra na Pismo Święte, w której Taxil pieczołowicie zwraca uwagę na wszelkie logiczne błędy oraz nieścisłości występujące w chrześcijańskiej świętej księdze. Swoisty drugi tom owego cyklu stanowi wydane w 1884 roku, równie prześmiewcze, La Vie de Jésus (Życie Jezusa). Taxil był autorem także dzieł pornograficznych, takich jak: Les Débauches d'un confesseur (Spowiedź spowiednika, 1882), Les Pornographes sacrés: la confession et les confesseurs (Święci pornografowie, 1882) czy Les Maîtresses du Pape (Metresy papieża, 1884), tematyką nawiązujących do kontrowersyjnych tekstów markiza de Sade i prezentujących duchownych jako nurzających się w rozpuście i luksusach bezwstydników. W międzyczasie Taxil na krótki czas dołączył do masonerii. W świetle kolejnych wydarzeń na szczególną uwagę zasługuje fakt, iż był on wolnomularzem zaledwie przez kilka miesięcy i nigdy nie wyszedł poza stopień ucznia ${ }^{24}$. Został inicjowany przez paryską lożę Temple des Amis de l'Honneur Français, przynależącą do Wielkiego Wschodu Francji 21 lutego 1881 roku, jedynie po to, by zostać erygowanym z jej szeregów decyzją trybunału dyscyplinarnego z 17 października 1881 roku ${ }^{25}$. Powodem usunięcia Taxila z grona wolnomularzy były jego nieustające ataki na Kościół, z którymi masoni nie chcieli być w żaden sposób utożsamiani.

Trzy lata później, w 1884 roku nastąpił zaskakujący zwrot akcji w życiu Taxila. Po publikacji encykliki Humanum genus autorstwa papieża Leona XIII (1810-1903), potępiającej ruchy wolnomyślicielskie, $w$ tym wolnomularzy, Taxil niespodziewanie publicznie ogłosił swoje nawrócenie na łono Kościoła ${ }^{26}$. W wydanych w 1884 roku

${ }^{23}$ K. McLeod, Pranksters..., s. 109.

${ }^{24}$ A.E. Waite, Diana Vaughan and the question of modern palladism, b.m.w., b.d.w., s. 9, tekst dostępny w zbiorach biblioteki UGLE w Londynie (call number: A 699 (PAL) WAI fol.).

25 D.A. Harvey, Lucifer in the City..., przypis nr 13, s. 181.

${ }^{26}$ Encyklika Humanum Genus stawia masonerii zarzut zniszczenia religii i Kościoła oraz odrzucenie Jezusa: „W tych szalonych i godnych napiętnowania zamiarach widoczna jest ta sama nieubłagana nienawiść i żądza odwetu, jaką Szatan pała przeciw Jezusowi Chrystusowi” (tłum. K. R., tekst encykliki dostępny online: Leon XIII, Humanum Genus, tekst dostępny online: http:// w2.vatican.va/content/leo-xiii/en/encyclicals/documents/hf_l-xiii_enc_18840420_humanum-genus.html [dostęp: 11.01.2019]). Taxil wyznał później, iż encyklika Humanum Genus stała się dla niego inspiracją do rozpoczęcia antymasońskiej kampanii i oskarżenia jej o praktykowanie satanizmu. Zob. D.A. Harvey, Lucifer in the City..., s. 187. Więcej na temat historii antymasonizmu kościelnego w: T. Cegielski, Od papieskiej bulli do tabloidu..., ss. 37-52. 
Confessions d'un ex-libre-penseur (Wyznania wolnomyśliciela) otwarcie wyjawił wszystkie swoje winy i wyraził chęć naprawy wyrządzonych szkód. Ta praca zapoczątkowała szereg antymasońskich tekstów, pełnych coraz bardziej wymyślnych fantazji na temat wolnomularzy i ujawniających rzekomy sekretny kult masonerii palladiańskiej, czczący samego Szatana pod imieniem Lucyfera. „Wszyscy członkowie wyższych stopni wtajemniczenia winni utrzymywać masońską religię w czystości doktryny lucyferiańskiej”27 - miał twierdzić domniemany przywódca palladystycznego kultu Albert Pike (1809-1891), w rzeczywistości zaś wolnomularz w ramach Rytu Szkockiego Dawnego i Uznanego (RSDU, ang. Ancient and Accepted Scottish Rite of Freemasonry), bohater wojny secesyjnej, prawnik, poeta oraz autor fundamentalnego dzieła Morals and Dogma of the Ancient and Accepted Scottish Rite of Freemasonry (Moralność i dogmaty wolnomularskiego Rytu Szkockiego Dawnego i Uznanego, 1872). Wątki poruszane przez Taxila na łamach takich tekstów, jak: Les frères Trois-Points (Bracia Trzech Punktów, 1885), Les soeurs maçonnes (Masońskie siostry, 1886), Les mysteres de la Franc-Maconnerie (Tajemnice masonerii, 1886), Le culte du Grand Architecte (Kult wielkiego architekta, 1886) i innych, całkowicie podbiły wydawców „La Franc-maçonnerie démasquée"28. Wydawcy niemal natychmiast zapadli na une taxilomanie chronique („chroniczną taxilomanię”) ${ }^{29}$. To pomogło Taxilowi uzyskać tytuł czołowego eksperta w dziedzinie antymasonizmu oraz pozwoliło mu zdobyć zaufanie katolickich duchownych - jeden z francuskich biskupów chętnie finansował publikację kolejnych wymysłów Taxila, a w 1887 roku sam papież Leon XIII przyjął go na audiencji.

Pièce de résistance antymasońskiej twórczości stało się dzieło pt. Le Diable au XIXe siècle (Diabeł w XIX wieku, 1892), napisane wspólnie z Charlesem Hacksem, przyjacielem z dzieciństwa ${ }^{30}$, i wydane pod zbiorowym pseudonimem niejakiego doktora Bataille, fikcyjnego lekarza okrętowego, prowadzącego śledztwo na temat palladyzmu. Podczas swojej podróży przez Azję i Europę doktor Bataille, ukryty pod osłoną fałszywej tożsamości, miał zinfiltrować szeregi masonów i poznać ich najbardziej skryte tajemnice. Książka obfituje w opisy diabelskich manifestacji ${ }^{31}$,

${ }^{27}$ J. Robinson, A Pilgrim's Path: Freemasonry and the religious right, M. Evans, New York 1993, s. 56, tłumaczenie autorki.

${ }^{28}$ „La Franc-maçonnerie démasquée” - periodyk Francuskiego Stowarzyszenia Antymasońskiego działającego we Francji na początku XX wieku, wydawany w latach 1884-1899.

${ }^{29}$ D.A. Harvey, Lucifer in the City..., s. 182.

${ }^{30}$ Część źródeł wspomina również o współautorstwie Domenico Margiotta, włoskiego antymasońskiego pisarza, autora takich pozycji, jak: Le Palladisme: Culte de Satán-Lucifer dans les triangles maçonniques (1895), Le Culte de la nature dans la franc-maçonnerie universelle (1896) czy Souvenirs d'un trente-troisième: Adriano Lemmi, chef suprème des francs-maçons (1894), do której wstęp napisał sam nieistniejący doktor Bataille. Zob. A. E. Waite, Devil-Worship in France: with Diana Vaughn and the Question of Modern Palladism, Weiser Books, 2003, ss. 202-224.

${ }^{31}$ Podczas palladiańskich seansów spirytystycznych jeden z demonów miał nawet objawiać się pod postacią skrzydlatego krokodyla, przygrywającego na pianinie. Zob. D.A. Harvey, Lucifer in the City..., s. 183. 
dematerializacji, tajnych satanistycznych obrzędów, włącznie ze składaniem ofiar z ludzi oraz sadystycznych i masochistycznych praktyk. Doktor Bataille miał też dotrzeć do Charlestonu w Stanach Zjednoczonych, rzekomej głównej kwatery satanizmu. Zgodnie z relacją doktora, przywódca palladystów - wspominany już Albert Pike - w każdy piątek o godzinie 15.00 spotykał się osobiście z Lucyferem (!). Wszyscy palladyści mieli także pracować nad realizacją tajnego planu zniszczenia katolicyzmu, jako jedynej prawdziwej wersji religii chrześcijańskiej, oraz przygotowania świata na przybycie Antychrysta. Le Diable au XIXe siècle stanowi zatem znakomite świadectwo XIX-wiecznego pseudosupernatualizmu. Taxil sprytnie zabezpieczył się także przed oskarżeniami o głoszenie nieprawdy w swoich publikacjach zamieścił informację, że tylko wybrani członkowie masonerii zostają wtajemniczeni w sekretną doktrynę i tajemne ryty. Jak ujął to sam Taxil: „Innymi słowy, było to najbardziej bezczelne wyzwanie rzucone ludzkiej głupocie - i zostało przyjęte”32.

Poza doktorem Bataille ogromnym wsparciem w oszustwie okazały się kreacje dwóch kobiet, najwyższych kapłanek palladystycznego kultu: niejakiej Diany Vaughan $^{33}$ - rzekomej potomkini Thomasa Vaughana, XVII-wiecznego filozofa i alchemika zajmującego się okultyzmem i wiedzą tajemną, oraz Sophie Walder prababki jeszcze nienarodzonego Antychrysta. Diana Vaughan miała nawrócić się na katolicyzm dzięki interwencji samej Joanny d’Arc i od tamtej pory działać na rzecz zniszczenia palladyzmu.

Coraz więcej wątpliwości narastających wokół publikacji Léo Taxila uczyniło z niego główny temat Antymasońskiego Kongresu, który odbył się w Trydencie w 1896 roku. Podczas sesji poświęconej sprawie palladystów niemiecki kleryk M. Baumgartner poprosił Taxila o dowód potwierdzający istnienie Diany Vaugan - jej akt urodzenia albo zaświadczenie od księdza, który uczestniczył w jej konwersji na katolicyzm i udzielił jej pierwszej komunii. Aby ratować sytuację, Taxil oświadczył, iż nie może podać takich informacji, gdyż wówczas życie Diany, poszukiwanej przez żądnych zemsty palladystów, znajdzie się w niebezpieczeństwie. Obiecał wszakże przekazać te dane papieskiemu wysłannikowi.

Choć owa obietnica uspokoiła na pewien czas krytyków Taxila, wkrótce kolejni oponenci zaczęli występować przeciwko niemu, otwarcie wykazując fałszywość zamieszczonych przez niego informacji bądź protestując przeciwko zniesławieniu (jak Adriano Lemmi, Wielki Mistrz Wielkiego Wschodu Włoch, czy Lilian Pike, córka Alberta Pike’a). Z kolei gdy papieski wysłannik, biskup Luigi Lazzareschi, zamiast

${ }^{32}$ A.E. Waite, Devil-Worship..., s. 246, tłum. autorki.

${ }_{33}$ Diana miała narodzić się 29 lutego 1874 roku. Już ta informacja powinna była wzbudzić podejrzenia czytelników Taxila, bowiem taka data nigdy nie istniała w XIX-wiecznym kalendarzu. Jako najwyższa kapłanka palladyzmu, Diana miała również za pomocą demonów odbyć podróże na Marsa, do chronionego przez anioły Edenu oraz na fikcyjną planetę Oolis, skąd powróciła na Ziemię poprzez krater wulkanu. Na potrzeby zdjęć w rolę Diany wcielała się stenotypistka Taxila. 
otrzymać oczekiwane informacje na temat Diany został odprawiony z serią wymówek, które nie mogły go usatysfakcjonować, w styczniu 1897 roku oświadczył, iż nie ma dowodu potwierdzającego bądź zaprzeczającego istnieniu Diany Vaughan.

Taxil, świadom, że dłużej nie jest już w stanie oszukiwać publiczności, zdecydował się ujawnić cały swój spisek i na zwołanej przez siebie 19 kwietnia 1897 roku w Paryżu konferencji oświadczył, iż zarówna palladyzm, jak i Diana Vaughan były całkowitą fikcją i istniały „tylko na papierze oraz w kilku tysiącach umysłów”34. Po czym dodał: „Palladyzm, teraz, jest martwy i to na dobre. Jego ojciec właśnie go zabił”35. Niestety, nie miał racji - część osób obecnych na konferencji nie uwierzyła nawet samemu Taxilowi, gdy ten ogłosił, że cały spisek nigdy nie istniał. Zamiast zaakceptować, iż zostali oszukani, woleli wierzyć, że to palladyści zastraszyli Taxila i zmusili go do wycofania się z rzucanych na nich oskarżeń. Część zaś spośród jego czytelników nigdy nie poznała prawdy na temat całej historii i w dobrej wierze przekazywała i rozpowszechniała dalej fikcyjne opowieści na temat masonerii palladiańskiej.

\section{Feliksa Eger a masoneria: wyniki analizy}

Feliksa Eger (1835-1908) to polska publicystka, której najbardziej znane teksty ukazały się na przełomie XIX i XX wieku. Początkowo pracowała jako bibliotekarka w Muzeum Pałacu Króla Jana III w Wilanowie, gdzie zajmowała się opracowywaniem i zabezpieczeniem cennych zbiorów ${ }^{36}$. W latach 90. XIX wieku przeniosła się do Zakopanego, gdzie wspólnie z rodziną prowadziła na Bystrem pensjonat Fortunka, w którym zatrzymywały się takie osobistości, jak lekarz i społecznik Kazimierz Dłuski, noblistka Maria Skłodowska-Curie, kompozytor Mieczysław Karłowicz czy poeta Tadeusz Miciński ${ }^{37}$. Eger zasłynęła głównie jako autorka Historii towarzystw tajnych. Dzieje wolnomularstwa (masonii) (1886), ale wydała również inne publikacje z zakresu antymasonizmu, takie jak: Kilka słów o masonerii (1901), Żydzi i masoni we wspólnej pracy (1908), a także pozycje o tematyce religijnej i historycznej: Katechizm dogmatyczno-historyczny czyli Przewodnik nauki religijnej młodemu wiekowi poświęcony (1873), Z niedawnych czasów: wspomnienia z Wilanowa (1901) oraz Religja w wiedzy (1904). Ponadto z Zakopanego nadsyłała korespondencję do różnych polskich czasopism, między innymi „Kroniki Rodzinnej”, zarówno w postaci oryginalnych prac, jak i przekładów, przeważnie o treści religijnej.

${ }^{34}$ D.A. Harvey, Lucifer in the City..., s. 200.

${ }^{35}$ Ibidem.

${ }^{36}$ W. Fijałkowski, Muzuem - rezydencja w Wilanowie, jego geneza, dzieje i współczesny stosunek do tradycji, „Studia wilanowskie” nr VI, Warszawa, 1980, s. 20.

${ }_{37}$ M. Pinkwart, Zakopiańskim szlakiem Mieczysława Karłowicza, http://www.pinkwart.pl/ karlowicz/rapsodia.htm [dostęp: 13.03.2019]. 


\section{Historia towarzystw tajnych}

Najbardziej popularna monumentalna antymasońska publikacja Eger pt. Historia towarzystw tajnych. Dzieje wolnomularstwa (masonii) ukazała się po raz pierwszy w 1886 roku nakładem wydawnictwa W. L. Anczyc. Niektórzy autorzy jako datę pierwszego wydania błędnie podają rok 1894 roku³. Książka doczekała się później kolejnych wydań i była na owe czasy uznawana za najlepsze opracowanie na temat masonerii ${ }^{39}$. W 1904 roku została wydana pod zmienionym tytułem, jako Historia masoneryi i innych towarzystw tajnych ${ }^{40}$. Co zasługuje na uwagę, autorka, pisząc Historię towarzystw tajnych, oparła się w dużej mierze na kontrowersyjnej antymasońskiej pracy francuskiego jezuity Nicolasa Deschampsa: Les societés secretes et la société ou philosophie de l'histoire contemporaine (1874-1876), co w efekcie doprowadziło do błędnego przypisywania autorstwa Historii Towarzystw Tajnych Deschampsowi. Książkę mylnie uznawano za tłumaczenie publikacji Deschampsa na język polski. Główne zarzuty, jakie autorka stawia masonerii w tej pracy, są zbieżne z oskarżeniami Kościoła, wyrażonymi w encyklikach, a także z obszerną rozprawą wspomnianego już wcześniej ks. Augustina Barruela. Feliksa Eger podnosi przede wszystkim zatem argument o sekretnej działalności wolnomularzy oraz wspomina o istnieniu ukrytej, wyższej masonerii. „Masonia wyższa istnieje jednak niezaprzeczenie, a masonia symboliczna jest jedynie parawanem, poza którem działanie prawdziwej masonii się ukrywa” - twierdzi bibliotekarka ${ }^{41}$. Dowodem na złe intencje wolnomularzy ma być także istnienie wielu różnych stopni i rytów, mających na celu „ukrycie prawdziwego źródła masonerii” ${ }^{42}$. „Że jednak tak nazwany sekret jest podstawą samej masonii, więc wszystko w niej oparte jest na kłamstwie. Kłamią starsi, kłamią młodsi, kłamią rytuały, kłamią członkowie miedzy sobą, loże zwyczajne ukrywają wielkie loże, stopnie symboliczne są osłoną wysokich stopni, nauka publicznie głoszona ukrywa naukę tajemną, obrządki i ceremonie śmieszne, są pokrywką działań skrytych, stowarzyszenie jawne, ukrywa stowarzyszenie tajne”43 - konstatuje autorka. Feliksa Eger omawia

${ }^{38}$ M. Pinkwart, J. Zdebski, 1988, hasło: Eger Feliksa, w: Nowy cmentarz w Zakopanem. Przewodnik biograficzny, Warszawa-Kraków, s. 44.

39 Ibidem.

40 Lista dodatków z wydania z 1904 roku: Dopełnienia. Dodatek do strony 15, Szkic praw narzuconych Francyi w ostatnich dwudziestu latach, Prawo przeciw kongregacyom w świetle prawdy, Lista Rzqdu z roku 1879, Dodatek z r. 1883 do listy ludzi na widowni politycznej stojqcych, podanej w r. 1879, Lista deputowanych wol:. mul:. z r. 1901, wraz ze wzmiankq z jakich źródeł wiadomość o nich zaczerpniętq została lub do jakiej loży należą, Warsztaty, których zebrania urzq̨dzaja się w pałacu W:. Ws:. Francyi przy ulicy Cadet Nr. 16 oraz Pisma masońskie.

41 F. Eger, Historia towarzystw tajnych. Dzieje wolnomularstwa (masonii), Kraków 1894, s. 6. Wszystkie cytaty przedstawione z zachowaniem oryginalnej pisowni.

42 Ibidem, s. 11.

43 Ibidem. 
także całą historię wolnomularstwa, wywodząc jego początki od herezji gnostyków, manichejczyków, albigensów oraz templariuszy, pomimo iż brak dowodów na istnienie powiązań pomiędzy owymi grupami a wolnomularstwem. Autorka opisuje również wiek oświecenia oraz działania takich osób, jak Fryderyk II czy Wolter jako rodzaj spisku, realizowanego wspólnie z masonami i mającego na celu zniszczenie chrześcijaństwa, co wyraźnie wskazuje na inspirację dziełem Barruela. Ich najważniejszym zadaniem do realizacji w owym czasie miało być pozbycie się jezuitów i przejęcie szkolnictwa oraz wychowania dzieci i młodzieży. Myślą przewodnią książki wydaje się być przekonanie, iż wszelkie zmiany społeczne i przewroty polityczne w czasach nowożytnych są kierowane i przeprowadzane przez wolnomularzy, którzy są zakulisową siłą kierującą historią. Co więcej, jak twierdzi autorka: „Idee socyalistyczne i komunistyczne są koniecznym wynikiem dogmatu i moralności masońskiej a tło ich stanowi materializm i naturalizm”44.

Informacje na temat satanizmu (a także antysemityzmu) znajdujemy dopiero w rozdziale XVIII: Gdzie szukać kierowników? Domówienie, w którym autorka tłumaczy, powołując się na książkę niejakiego C. de Saint-André pt. Francs-maçons et Juifs (Wolnomularze i Żydzi, 1880), iż to właśnie Żydzi kierują wszelkimi tajnymi stowarzyszeniami, w tym wolnomularstwem.

Ster wszelkich związków jest dziś w ręku Żydów. Naród żydowski od niepamiętnych czasów tworzy sam olbrzymie towarzystwo tajne. Rozproszony wśród innych narodów, podległy im, żywi do nich straszną nienawiść, a przekonany o swej wyższości, dumny tradycyą, chce wszelkiemi możliwemi sposobami zawładnąć tymi, których władza bardzo mu jest uciążliwą ${ }^{45}$ - pisze Eger.

Następnie autorka przechodzi do kwestii satanizmu. Tak pisze o wpływie masonerii na społeczeństwo:

Gdy pomyślimy o tem dobrowolnem upodleniu natury, o zniżeniu się aż do poziomu zwierząt, o zerwaniu rozmyślnem wszelkich węzłów łączących człowieka ze Stwórcą, o wojnie wypowiedzianej Bogu, zwierzchności i całemu społeczeństwu, przychodzi pomimowolnie na myśl, że to chyba szatan zagościł w duszach tych ludzi, w których nic nie ma z Boga i którzy też, jakby dla przekonania o prawdzie tego twierdzenia, szatanowi i złemu cześć publiczną oddają. [...] Objawy czci szatana występują teraz szczególnie we Włoszech częściej aniżeli by to przypuścić można. W dziejach masonii widzimy po wiele razy, że największe jej potęgi uległy rodzajowi obłędu, który ich pchał do oddania czci szatanowi ${ }^{46}$.

Fragment ten ewidentnie inspirowany jest nauczaniem Kościoła katolickiego, w tym zwłaszcza encykliką Humanum Genus.

\footnotetext{
${ }^{44}$ Ibidem, s. 383.

45 Ibidem, ss. 423-424.

${ }^{46}$ Ibidem, ss. 438-439.
} 


\section{Kilka słów o masonerii}

Kilka słów o masonerii to kolejna pozycja Feliksy Eger na temat wolnomularstwa, wydana w 1901 roku przez wydawnictwo „Kroniki Rodzinnej”. Autorka już na wstępie przestrzega przed wolnomularstwem, a także przed Żydami:

Przed laty kilkudziesięciu na zapytanie: „,zem jest Masonerya?” nie bylibyśmy mogli odpowiedzieć lub dalibyśmy o niej najbłędniejsze pojęcie, dziś, widząc owoce jej prac, dokładnie możemy określić; jest to stowarzyszenie, dążące do zniesienia religii, rodziny, własności, do wywrócenia porządku społecznego, a zaprowadzenia jednej wielkiej rzeczypospolitej masońskiej w której ludzie byliby pionkami na wielkiej szachownicy świata, działającymi pod kierunkiem przywódzców Masonerji, którymi jak w obecnej chwili są żydzi ${ }^{47}$.

Fragment ten jest również swego rodzaju podsumowaniem treści książki, w której autorka powtarza głównie postulaty z Historii towarzystw tajnych, skupiając się przede wszystkim na objaśnianiu kolejnych działań związanych z realizacją tajnego spisku przejęcia władzy nad światem i ponownie analizuje wątki dotyczące rewolucji francuskiej, zjednoczenia Włoch i Niemiec, a także działań masonów w różnych krajach, mających na celu demoralizację społeczeństwa. Niektóre akapity są niemalże dosłownymi cytatami z poprzedniej książki - wystarczy chociażby porównać wstęp do rozdziału XVIII z Historii towarzystw tajnych ${ }^{48}$, z fragmentem pochodzącym z XI rozdziału Kilku słów o masonerii ${ }^{49}$. Autorka cytuje również dzieło niejakiego Adama Morawskiego Ze skarbnicy wiedzy i prawdy oraz sprostowanie błędnie podanych faktów historycznych i wyjaśnienie najdonioślejszych kwestyj naukowych, filozoficznych, społecznych i t. $p .^{50}$, który tak opisuje wolnomularzy:

Hasłem Woltera i bezbożnego w XVIII wieku sprzysiężenia się Masonów przeciwko katolicyzmowi było: Ecrasez l'Infame (Niweczcie bezecność). Tego samego hasła używa dziś cała Masonerya, a bluźnierczych jej mów nie podobna tu przytoczyć. Czytającemu takowe zdaje się, że o Kościele, o katolicyzmie i jego instytucyach z większą złością, nienawiścią i wściekłością nawet sam Lucyper nie potrafiłby się wyrażać. Ich złośliwość równa się wściekłości Żydów, gdy Chrystusa Pana krzyżowali ${ }^{51}$

${ }^{47}$ F. Eger, Kilka słów o masonerii, Warszawa 1901, s. 6.

${ }^{48}$ Ibidem, s. 363.

49 Ibidem, s. 58.

${ }^{50}$ Oryginalna publikacja dostępna w zbiorach Biblioteki Narodowej: A. Morawski, Ze skarbnicy wiedzy i prawdy oraz sprostowanie błędnie podanych faktów historycznych $i$ wyjaśnienie najdonioślejszych kwestyj naukowych, filozoficznych, społecznych i t. p. / zaczerpną i oprac. Adam Morawski. Wyd. 2. popr. i pomn. na tle postępu nauk i nowych odkryć, Gebethner i Wolff, Warszawa, 1884.

${ }^{51}$ F. Eger, Kilka słów..., ss. 64-65. 
Jest to jedyne nawiązanie do Szatana, jakie pojawia się w tej publikacji Feliksy Eger, w jednoznaczny sposób inspirowane zarzutami stawianymi wolnomularstwu przez Kościół katolicki. Również zatem tutaj autorka pozostaje na gruncie wizerunku masonerii jako wroga narodu, zaś cytowane przez nią porównanie działalności masonerii do poczynań Lucyfera ma za zadanie jedynie podkreślić ogrom potępienia, na jakie zasługują zdaniem Kościoła katolickiego wolnomularze.

\section{6. Żydzi i masonii we wspólnej pracy}

Żydzi i masonii we wspólnej pracy to ostatnia już pozycja Feliksy Eger, a zarazem najciekawsza do analizy, gdyż dopiero tutaj autorka skupia się na wątkach satanistycznych. Książka po raz pierwszy ukazała się w 1908 roku w Warszawie, nakładem Księgarni Nakładowej M. Szczepkowskiego. Autorka tym razem podpisuje się jako F. Eger, widoczna jest zatem ewolucja w sygnowaniu tekstów nazwiskiem: od całkowitej anonimowości w przypadku Historii towarzystw tajnych, poprzez inicjały, aż do pierwszej litery imienia oraz pełnego nazwiska ${ }^{52}$. Publicystka informuje czytelnika już na wstępie, iż tytuł została wydany celem udowodnienia wielowiekowej pracy masonerii i Żydów nad „podkopaniem społeczeństwa chrześcijańskiego" 53 . W pierwszej części publikacji głównym przedmiotem jej zainteresowania są powiązania między Żydami a masonami oraz sekretny kult satanizmu praktykowany na wyższych stopniach wtajemniczenia wolnomularskiego. W drugiej części natomiast omówiona zostaje historia Żydów, ich aktualna aktywność oraz powiązania z socjalizmem i anarchizmem. Jak bowiem przestrzega autorka: „Najniebezpieczniejszym z Żydów jest Żyd mason lub socjalista: prowokator, szpieg, wywołujący strajki, oszukujący, wywodzący w pole i biednego, ufającego mu robotnika i rząd, który się nim posługuje"54. Eger odwołuje się także do sięgających korzeniami czasów antycznych mitów na temat żydowskich mordów rytualnych ${ }^{55}$ : „Szczególną nienawiścią tchną Żydzi do dzieci. Herod kazał je wyciąć; w wiekach średnich Żydzi puszczali za nich krew, męczyli i krzyżowali; teraz Żydzi i Wol.: MuL: gorzej z niemi postępują, bo każą ich serca i umysły, wydzierają z nich wszystko, co zacne i szlachetne"56. Masoneria ma być również zdaniem autorki wojskiem podlegającym Żydom oraz siłą panującą nad światem

${ }^{52}$ Oczywiście, nie znamy przyczyn nieumieszczenia na okładce pierwszego dzieła nazwiska autorki, które pojawia się dopiero we wstępie do Historii towarzystw tajnych, lecz być może, z uwagi na podejmowaną tematykę, autorka początkowo wolała mniej się wyróżniać, spodziewając się zemsty ze strony „groźnego” bractwa masonów.

${ }^{53}$ F. Eger, Żydzi i masoni we wspólnej pracy, Warszawa 1908, s. 5.

${ }^{54}$ Ibidem, ss. 11-12.

${ }_{55}$ Por. A. Dundes, The Blood Libel Legend: a casebook in anti-Semitic folklore, University of Wisconsin Press, 1991.

${ }^{56}$ F. Eger, Żydzi i masoni..., s. 12. 
politycznie, podczas gdy Żydzi mają sprawować nad nim władzę finansową, co z kolei wydaje się być wątkiem wprost zaczerpniętym z Protokołów Mędrców Syjonu $^{57}$ (1903), fałszywki wykonanej przez carską Ochranę i będącej przeróbką kilkunastu innych utworów, w tym głównie satyry autorstwa Maurice’a Joly’ego pt. Rozmowy w piekle między Monteskiuszem i Machiavellim oraz powieści Biarritz Hermana Goedsche ${ }^{58}$.

Aby udowodnić powiązania między masonami a Żydami, autorka powołuje się również na wspominanego już w Historii towarzystw tajnych Nicolasa Deschampsa, który twierdzi, że „twórcami Wol.: Mularzy Illuminatów i Martynistów byli żydzi” ${ }^{59}$. Żydów i masonów ma również łączyć wyznawanie kabały, w tym wiara w szczególne znaczenie liczb 11 i 3360 a także satanizm. Jak bowiem pisze Eger: „Żydzi kabaliści, odstąpiwszy od wiary Objawionej, naturalnem następstwem zbuntowali się przeciw Bogu, oddając się dobrowolnie w służbę szatana, na wzór narodów bałwochwalczych" ${ }^{61}$. W kolejnych fragmentach ubolewa natomiast: „Rzadko jednak przewrotność ludzka doszła do nazwania Boga - Lucyferem, a Lucyfera - Bogiem. To jednak miało miejsce w sekcie Ofitów, poprzedników Wol.: Mularzy. Czcili oni Lucyfera pod postacią węża [...] Cześć szatanowi jest oddawaną w wielu obrządkach Wol.: Mul.:, ale większość chrześcijan masonów nie przypuszcza nawet tego"62. Autorka pisze też o rzekomym Eblisie (Szatanie), który ma być obiektem kultu wolnomularzy, oraz o odwróceniu tradycyjnych chrześcijańskich wartości:

Eblis uważany jest za najwyższe bóstwo masońskie, przyjaciela ludzi, a przeciwnika zaciętego Boga Adonai. Jest on istotą przedwieczną, odradzającą się zawsze przez ogień, który jest jego żywiołem. Nazywają go bogiem światła, bogiem ognia, inteligencją, mądrością, siłą, W. Architektem. Świątynią tego Architekta świata budowaną przez Hirama - jest królestwo szatana na ziemi. [...] Połączeni razem ci przyjaciele Eblisa tworzą Wol. Mul., będące najwyraźniejszym objawem związku między upadłymi aniołami, upadłą Synagogą i upadłym Zakonem ${ }^{63}$.

Zdaniem autorki także kolejne stopnie wtajemniczenia masońskiego są w rzeczywistości stopniami wtajemniczenia w satanizm, a na trzydziestym stopniu wtajemniczenia kandydat ma być wprost informowany, iż jego prawdziwym obiektem

57 Zob. Protokoły Mędrców Syjonu, bmw 1919, ss. 18-20, http://wojtek.pp.org.pl/pliki/notki/2019-02-12_protokoly-medrcow-syjonu-skladnica/Protoko\%C5\%82y\%20Medrc\%C3\%B3w\%20Syjonu\%20z\%201919\%20roku\%20w\%20formacie\%20PDF.pdf [dostęp: 20.12.2019].

${ }^{58}$ Więcej na temat Protokołów Mędrców Syjonu w: J. Tazbir, Protokoły mędrców Syjonu: autentyk czy falsyfikat, Wydawnictwo Interlibro, Warszawa,1992.

${ }^{59}$ F. Eger, Żydzi i masoni..., s. 44.

${ }^{60}$ Ibidem, s. 45.

${ }^{61}$ Ibidem.

62 Ibidem, s. 46.

${ }^{63}$ Ibidem, s. 63. 
kultu jest Bafomet (Szatan) ${ }^{64}$. Eger opisuje również odwrócone rytuały katolickie odprawiane podczas uczty masońskiej (którą, co warto zauważyć, autorka mylnie określa mianem areopagu, nie zaś agapy).

Szczytem objawu złości szatańskiej przeciw Bogu jest gest symboliczny Kadoszów, kiedy w czasie bankietu, przy wznoszeniu szóstego zdrowia, zanurzają wszyscy sztylety w szklankach z winem czerwonym, a gdy krople tego wina ściekają, wszyscy razem wznoszą okrzyk: „Deussanctus Nencam” (Boże święty mścicielu.) Po wypiciu uderzają sztyletem jakby w stronę nieba, wołając: „Necam Adonai” (Zemsta Adonai.) Zemsta przeciwka Tobie, Bogu Chrześcijan, zemsta za wszystko złe, wyrządzone Lucyferowi”5.

W książce znajdziemy także cały rozdział „O znaczeniu liczb znaków, symbolów, trawestowaniu obrządków i czci szatana”. Autorka wspomina również o roli, jaką w kulcie pełnić ma „Albert Picke” (autorka ma oczywiście na myśli Alberta Pike’a), wzorując się zapewne na fantazjach Léo Taxila; wspomina nawet o jego rzekomej świątyni satanistów w Charlestonie ${ }^{66}$ oraz twierdzi, jakoby masoni uważali się za potomków samego szatana (!):

Masoni w legendach swych opowiadają, że pochodzą od Kaina, Lemecha, Tubalkaina, Chanaana, Hirama i że Kain był nieprawym synem Ewy i Eblisa, czyli szatana. Genealogja taka upoważnia ich do oddawania czci swemu protoplaście. Stąd też Żydzi i Wol. Mul. utrzymują, że należą do rasy wyższej od ludzkiej, i to jest także jednym punktem więcej zbliżenia między nimi. W tym też duchu pracując, Albert Pike postanowił ponad wszystkimi obrządkami świata stojącą Mas. wyższz̨, jawnie Lucyferjańską, której władza zwierzchnia uznaną i przyjętą jest przez wszystkich Wol. Mul. Czczą oni szatana, pod nazwami: W-go Architekta świata, Eblisa, Mistrza Jehowah, Anioła ciemności, podstawę dobra, Lucyfera, równego Adonai, który na nieszczęście jest także Bogiem ${ }^{67}$.

Dopiero zatem ostatnie z dzieł Feliksy Eger prezentuje wizerunek masonerii jako organizacji satanistycznej, kultywującej odwrócone rytuały i przewodzonej przez Alberta Pike’a - rzekomego najwyższego kapłana, urzędującego w Charlestonie i wprost czerpie z czarnej legendy wolnomularstwa, skonstruowanej przez Léo Taxila ponad dwadzieścia lat przed wydaniem książki.

\section{Zakończenie}

Jakkolwiek Taxil oskarżył masonów o wiele różnych rzeczy, na uwagę bezsprzecznie zasługuje fakt, iż w żadnym ze swoich dzieł nie powiązał ich działań z Żydami, a głównymi antybohaterami książki pozostają angielscy i amerykańscy protestanci. Co więcej, sam Taxil, pod swym nom de plume Diany Vaughan, wy-

\footnotetext{
${ }^{64}$ Ibidem, s. 75.

65 Ibidem, s. 78.

${ }^{66}$ Ibidem, ss. 85, 87.

${ }^{67}$ Ibidem, s. 89 .
} 
stępował przeciwko antysemityzmowi we Francji ${ }^{68}$, jednocześnie zaś krytykując sam siebie (!) ustami swego drugiego alter ego, czyli Léo Taxila, za niezwrócenie dostatecznej uwagi na kwestię żydowską podczas swoich badań nad masonerią ${ }^{69}$. Antysemickie wątki w taxilowskiej odnodze antymasonizmu pojawiły się zresztą dopiero w wydanej w 1893 roku La franc-maçonnerie, synagogue de Satan (Masoneria - synagoga szatana). La franc-maçonnerie, synagogue de Satan napisana została przez francuskiego arcybiskupa rezydującego na Mauritiusie, Leo Meurina. W swojej książce Meurin wymieszał oba wątki, czyli zarzuty stawiane wolnomularzom, z pomówieniami wobec Żydów, odwołując się nawet do oskarżeń o mordy rytualne oraz dążeń do przejęcia władzy nad światem. Dzieło pełne jest cytatów z publikacji Taxila, którego Meurina uznał za wiarygodnego eksperta w kwestii antymasonizmu. Efektem było powstanie książki poświęconej historii światowego żydomasońskiego spisku. Temat ten został także później rozpropagowany przez wspominane już Protokoły Mędrców Syjonu. Jako że tekst Żydzi i masonii we wspólnej pracy ukazał się pięć lat później, trudno jest stwierdzić, które spośród wspomnianych publikacji stanowiły faktyczną inspirację dla autorki, tym bardziej, że inaczej niż w Historii towarzystw tajnych, tym razem bibliotekarka nie powołuje się na żadnych autorów i jedynie z rzadka podaje źródła swych informacji. Na uwagę zasługuje wszakże fakt, iż Feliksa Eger nie posługuje się takim terminem, jak „masoneria palladiańska”, ani nie wspomina o tak znaczącej dla satanistycznego mitu ukutego przez Taxila osobie, jaką była Diana Vaughan, co wskazuje, że jeśli miała jakąś styczność z oryginalnymi publikacjami Taxila, to jedynie w ograniczonej liczbie. Publikacje Feliksy Eger są jednak znakomitym świadectwem potwierdzającym zasięg i siłę wpływu teorii spiskowych, zwłaszcza zaś mitów stworzonych przez Taxila, na wizerunek wolnomularstwa. W analizowanych tekstach widoczna jest również ewolucja wizerunku wolnomularstwa - od obrazu ściśle powiązanego ze stosunkiem Kościoła katolickiego wobec masonerii, choć też nie wolnego od pomówień i wymysłów, do całkowicie zmyślonej historii rzekomego satanistycznego spisku.

Oszustwo Taxila było i pozostaje zatem jednym z największych fenomenów XIX wieku. Jego utwory publikowali najbardziej prominentni katoliccy wydawcy, na łamach takich magazynów, jak „La Franc-maçonnerie démasquée” czy „Revue Catholique”, a arcybiskup Grenoble Armand-Joseph Fava regularnie informował swoich wiernych o postępach w sprawie antymasońskiej krucjaty Diany Vaughan. Niemniej część spośród katolików zauważyła, iż otrzymali właśnie bardzo gorzką nauczkę od Taxila. Jak pisał jeden z wydawców:

Przy całej odrazie, jaką żywimy do Léo Taxila i jego pomocników, nie możemy zaprzeczyć, iż, przypadkowo oczywiście, dokonał on czegoś dobrego. Powinien nadejść

${ }^{68}$ D.A. Harvey, Lucifer in the City..., s. 203.

${ }^{69}$ Ibidem, ss. 203-204. 
koniec dla wszelkich historii o fantastycznych istotach, głupcach, zmyślonych nawróceniach, które kłamcy bez sumienia oferowali publice w charakterze odkryć, sekretów i przepowiedni ${ }^{70}$.

Niestety, nie wszyscy wyciągnęli równie słuszne wnioski z owej historii.

\section{Literatura}

Berlet Ch., Toxic Democracy. Conspiracy theories, demonization and scapegoating, „Political Research Associates” 2009, https://www.academia.edu/6928596/Toxic_to_Democracy_Conspiracy_Theories_Demonization_and_Scapegoating [dostęp: 20.12.2019].

Byford J., Conspiracy theories: A Critical Introduction, Basingstoke 2011.

Cegielski T., Od papieskiej bulli do tabloidu. Krótki zarys dziejów antymasonizmu, „Hermaion” 2015, nr 4.

Di Bernardo G., 1993, Definicja Masonerii, tłum. J. Wysocka, „Ars Regia. Czasopismo poświęcone myśli i historii wolnomularstwa” 1993, Rok 2, nr 1(2).

Dundes A. The Blood Libel Legend: a casebook in anti-Semitic folklore, University of Wisconsin Press, 1991.

Eger F., Historia towarzystw tajnych. Dzieje wolnomularstwa (masonii), G. Gebethner i Spółka, Kraków 1894.

Eger F., Kilka słów o masonerii, Kronika Rodzinna, Warszawa 1901.

Eger F., Żydzi i masoni we wspólnej pracy, Księgarnia Nakładowa M. Szczepkowskiego, Warszawa 1908.

Fijałkowski W., Muzeum - rezydencja w Wilanowie, jego geneza, dzieje i współczesny stosunek do tradycji, „Studia wilanowskie” nr VI, Warszawa, 1980.

Grzesiak-Feldman M., Psychologia myślenia spiskowego, Wydawnictwo Uniwersytetu Warszawskiego, Warszawa 2016.

Guzowski J., Psychologiczne źródła teorii spiskowych, „HYBRIS” 2016, nr 33, http://hdl. handle.net/11089/20139 [dostęp: 20.12.2019].

Harvey D.A., Lucifer in the City of Light, „Ritual \& Witchcraft” Winter 2006, t. 1, nr 2.

Korzeniowski K., O dwóch psychologicznych przesłankach myślenia spiskowego. Alienacja czy autorytaryzm, „Psychologia Społeczna” 2009, t. 4, nr 3(11), http://www.spoleczna. psychologia.pl/pliki/2009_3/Korzeniowski_PS_2009_3.pdf, [dostęp: 13.03.2019].

Leon XIII, Humanum Genus, http://w2.vatican.va/content/leo-xiii/en/encyclicals/documents/hf_l-xiii_enc_18840420_humanum-genus.html [dostęp: 11.01.2019].

McLeod K., Pranksters: Making Mischief in the Modern World, NYU Press, New York 2014.

Metody badania wizerunku w mediach. Czym jest wizerunek, jak i po co należy go badać, red. T. Gackowski, M. Łączyński, CeDeWu, Warszawa 2009.

Pinkwart M., Zakopiańskim szlakiem Mieczysława Karłowicza, wydanie internetowe, http:// www.pinkwart.pl/karlowicz/rapsodia.htm [dostęp: 13.03.2019].

Pinkwart M., Zdebski J., hasło: Eger Feliksa, w: Nowy cmentarz w Zakopanem. Przewodnik biograficzny, Warszawa-Kraków 1988.

${ }^{70}$ Za: K. McLeod, Pranksters..., s. 112, tłumaczenie autorki. 
Pipes D., Potęga spisku. Wpływ paranoicznego myślenia na dzieje ludzkości, Bej Service, Warszawa, 1998.

Protokoły Mędrców Syjonu, bmw 1919, http://wojtek.pp.org.pl/pliki/notki/2019-02-12 protokoly-medrcow-syjonu-skladnica/Protoko\%C5\%82y\%20Medrc\%C3\%B3w\%20 Syjonu\%20z\%201919\%20roku\%20w\%20formacie\%20PDF.pdf [dostęp: 20.12.2019].

Roberts J.M., The Mythology of the Secret Societies, Charles Scribner's Sons, New York 1972.

Robinson J., A Pilgrim's Path: Freemasonry and the religious right, M. Evans, New York 1993.

Rosiak K., Wizerunek masonerii w polskich memach internetowych, w: Memy czyli życie społeczne w czasach kultury obrazu, red. T. Gackowski, K. Brylska, M. Patera, CeDeWu, Warszawa 2017.

Sorman G., Prawdziwi myśliciele naszych czasów, tłum. M. Miszalski, Czytelnik, Warszawa 1993.

Tazbir J., Najnowsze publikacje na temat Protokołów mędrców Syjonu, „Dzieje Najnowsze” 1992, R. XXIV, nr 4.

Tazbir J., Protokoły mędrców Syjonu: autentyk czy falsyfikat, Wydawnictwo Interlibro, Warszawa 1992.

Waite A.E., Devil-Worship in France: with Diana Vaughn and the Question of Modern Palladism, Weiser Books, York Beach 2003.

Waite A.E., Diana Vaughan and the question of modern palladism, b.m.w., b.d.w., s. 9, tekst dostępny w zbiorach biblioteki UGLE w Londynie (call number: A 699)

Zdybel L., Idea spisku i teorie spiskowe w świetle analiz krytycznych i badań historycznych, Wydawnictwo UMCS, Lublin 2002. 
